\title{
Russia to focus science on high-tech goals
}

[MOSCOW] Russia's minister of science and technology, Mikhail Kirpichnikov, has put forward a package of measures which, he argues, need to be introduced if Russia is to use its scientific achievements to boost its capacity for technological innovation.

The package includes economic and legislative means for stimulating investment in science-based production; insurance cover for such investment; and financial support for enterprises that engage in such production. Resources would be directed towards projects that use high technology to achieve commercial goals, as well as contributing to social priorities and national security, and helping to reduce imports.

The new measures' goal was endorsed in President Boris Yeltsin's annual message to the Federal Council (the Russian parliament) last week. Yeltsin described science and technology as "strategic prerequisites for the growth of the national economy - and hence the improvement of the quality of life".

Kirpichnikov's ideas have already been endorsed by the cabinet, but his strategy differs significantly from previous approaches to the administration of Russian science.

First, it deals only with a limited period of less than one year. "This is because it is difficult nowadays to make plans for a longer perspective," explains Kirpichnikov, who is a full

member of the Russian Academy of Sciences. Second, his ministry is, for the first time, basing its approach not on pointing out the extra money science needs - a strategy that has met little success in the past - but on asking what science can contribute to the economy.

"To achieve the standards of life typical for developed countries we need to increase our gross national product," says Kirpichnikov. "There are three ways of doing this. Russia is too big to rely totally on selling its raw materials - it takes a few thousand kilometres to transport oil or gas to the Russian frontiers and we cannot afford new technologies. The only option left is through innovation, based on the fact that Russia still has powerful fundamental science and has managed to keep its intellectual potential in spite of the fact that in the last 10 years it lost half of its scientists."

Kirpichnikov argues that the way out of the economic crisis is by using Russia's scientific and intellectual potential to create hightech production, selling patents and knowhow. But he points out that two obstacles stand in the way: the lack of strong demand from industry and agriculture, caused by the difficult economic situation, and an underdeveloped infrastructure for innovation.

It is to overcome the first barrier that Kirpichnikov has suggested the measures to be taken at government level. Another sugges-

\section{US spallation project 'running into trouble'}

[WASHINGTON] A prominent Republican Congressman says that management of the US Spallation Neutron Source (SNS) at the Oak Ridge National Laboratory in Tennessee is "in turmoil". He wants construction of the $\$ 1.4$ billion facility to be halted until the management problems are fixed.

James Sensenbrenner (Republican, Wisconsin), chairman of the Science Committee in the House of Representatives, visited the project last month before publishing a blistering critique of the Department of Energy's management of it. The SNS is the largest scientific user facility that the department has attempted to build since the Superconducting Super Collider project, abandoned in Texas in 1993.

"SNS project management is in turmoil, spending is lagging, and project cost and schedule estimates have not been fully developed," says Sensenbrenner. He adds that the energy department's effort to share responsibility for the project among five laboratories requires simplification.

Sensenbrenner's attack on the project which he says he still supports - follows a difficult winter for the spallation source. Events culminated in the replacement in February of the project director, Bill Appleton of the Oak Ridge laboratory, by

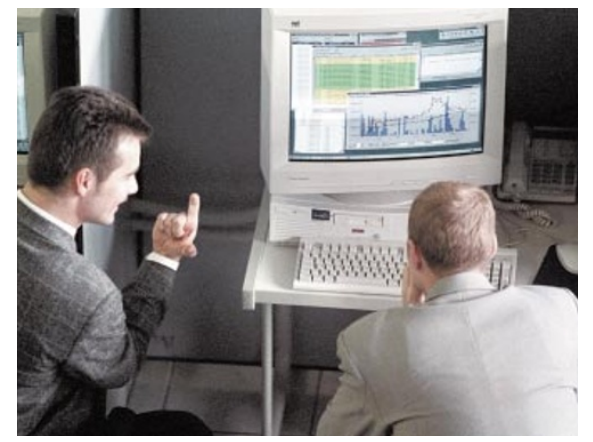

Technology's our one hope: traders track the economy at the Moscow stock exchange.

tion is that the stable functioning of scientific organizations could be ensured by their winning orders from the state for high-technology products through competitive bidding.

Kirpichnikov adds that the science ministry is seeking to overcome the second obstacle by setting up a series of Innovation-Technological Centres (ITCs). These bring together small companies able to transform scientific results into competitive industrial production. They are situated in half-empty or incomplete buildings of factories or scientific institutions, and modestly supported by local and federal budgets.

There are now 18 ITCs, with more than 250 small companies and 7,000 scientists, and 17 more centres are to be set up. ITCs have shown they can speed the innovation process by up to three times while halving costs. They return the initial budget funding within one or two years by paying taxes.

The annual cost of products sold per scientist linked with an ITC equals US\$15,000-25,000 — higher than average for Russia. But Kirpichnikov points out that each rouble invested in ITC activities can bring in five to 12 roubles a year.

Kirpichnikov considers the ITCs to be only the first link in the innovation chain. This year, the science ministry will also create two or three Federal Centres for Science and High Technologies, which will bring together around a leading scientific organization universities, design offices, standardization and certification centres, as well as factories.

Such centres will concentrate their efforts in fields in which small companies are unable to solve the problems, such as aircraft production, shipbuilding and energy production. Federal centres based on the country's biggest enterprises are expected to surpass the production of the ITCs by 10-100 times.

"All these will allow us as soon as the end of this year to make a real move towards the high-technology economy," says Kirpichnikov. He promises that in 2000 the government will increase science funding to no less than 4 per cent of all state spending, as promised by Yeltsin in $1996 . \quad$ CarlLevitin
Republican supporters, including Senator Bill Frist of Tennessee.
Colin Macilwain 